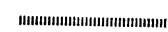 論 文 連続鋳造におけるタンディッシュ内溶鋼 (C) 1985 ISIJ 加熱による非金属介在物の低減
}

\author{
吉井裕*. 野崎 \\ 努*2 . 坦生 泰弘 ${ }^{* 3}$ \\ 上田 典弘 ${ }^{* 4} \cdot$ 針田 涁*. 桜井 美弦*5

\section{Decreasing Non-metallic Inclusions in Molten Steel by Use of Tundish Heating System in Continuous Casting} \\ Yutaka YoshiI, Tutomu Nozaki, Yasuhiro HabU, \\ Tsunehiro UEdA, Akira HARITA and Mituru SAKuraI
}

\section{Synopsis :}

Tundish-heater by utilizing channel type electromagnetic induction heating method has been newly developed to prevent the temperature drop of molten steel in tundish at the start, the end of casting and the ladle change in continuous casting. The effect of tundish-heater on temperature of molten steel and qualities of cast slabs of stainless steels have been investigated.

The results obtained are as follows :

1) The degree of the temperature drop of molten steel in tundish without heater at the start of casting is $10 \sim 20^{\circ} \mathrm{C}$, on the contrary that with tundish-heater to be $0 \sim 5^{\circ} \mathrm{C}$. Temperature drops at the end of casting and the ladle change can be perfectly prevented.

2) Number of the subsurface inclusions in stainless steel slabs cast at such unsteady states decreases to $1 / 4 \sim 1 / 12$ compared with that of slabs cast without heating. Surface and internal qualities of coldrolled sheets are also improved to the level of the sheets cast at steady state.

3) The strong stirring of molten steel in tundish by electromagnetic force can be considered as one of the effect of removal of large inclusions.

\section{1. 緒}

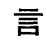

連続鋳造時の鋳込初期や末期，および取鍋交換部など の非定常部鋳片は，定常鋳込部の鋳片と比較して一般的 に品質が劣ることが知られている1) 5)．これは非定常部 特有の治金要因に起因する・たとえば溶鋼の再酸化や耐 火物の溶損，および各種スラグの混入の機会が多くなる ことや，非定常鋳込相当部は低温になるために介在物の 浮上分離が十分に促進されないこと, およびモールドハ ウダーの溶融不足によつて，ハウタダーが鋳片表皮下に捕 捉されやすくなる，などのためと考学られる。

これらの問題に対しては従来から種々の観点から防止 法が検討されて, 有効な対策が実施されてきた結果6) 8), 非定常部鋳片の品質は著しく向上してきている.

しかしながら，品質要求水準の厳しい高級鋼の分野に
おいてはいまだ非定常部の連鋳鋳片の手入れ工数比率は 高く, 製品への充当規制も厳しく, 一段と有力な品質向 上対策が要求されている.

本報告では非定常部鋳片の品質改善法として, タンデ ィッシュ内溶鋼温度低下に着目し, 溝型電磁誘導炉を用 いたタンディッシュ内溶鋼の加熱方法を実生産規模のス テンレス鋼鋳造に適用した結果 ${ }^{9)}$ １3）有益な知見が得ら れたので報告する。

\section{2. 実 験 方 法}

実験は千葉製鉄所，第 1 連鋳機（全湾曲型スラブ連鋳 機, $R=10.0 \mathrm{~m})$ の $7 \mathrm{t}$ 容量のタンディッシュを用い て, ステンレス鋼鋳造時にタンディッシュ内溶鋼加熱を 行つた。加熱は主として鋳込初期，末期および取鍋交換 時の溶鋼温度低下防止と, 鋳込中期にお忛る目標鋳造温 昭和 58 年 4 月. 59 年 4 月本会講演大会にて発表 昭和 59 年 12 月 27 日受付 (Received Dec. 27, 1984)

* 川崎製鉄 (株) ハイテク研究所 (High-Technology Research Laboratories, Kawasaki Steel Corp., 1 Kawasaki-cho Chiba 260)

*2 川崎製鉄 (株) 鉄鋼研究所 理博 (Iron \& Steel Research Laboratories, Kawasaki Steel Corp.)

*3 川崎製鉄 (株) 研究企画部 I博 (Research Planning Dept., Kawasaki Steel Corp.)

*4 川崎製鉄 (株) ツバロン製鉄協力部 (Technology Co-ordination Section, Kawasaki Steel Corp.)

*5 川崎製鉄 (株) 千葉製鉄所 (Chiba Works, Kawasaki Steel Corp.) 


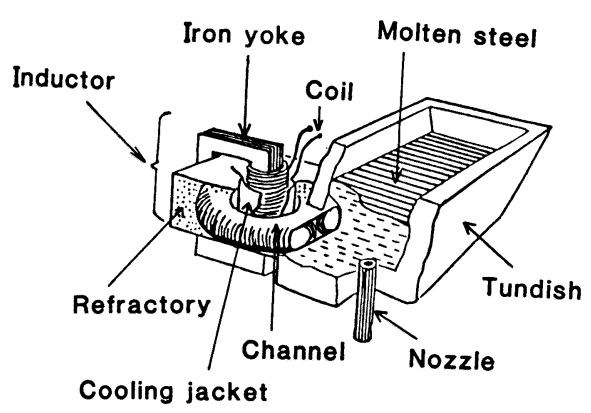

Fig. 1. Principle and construction of induction heater.

度の定温保持に適用した。

また一部のヒートでは鋳込中期に，溶鋼過熱度を任意 に变化させ，鋳込温度の鋳片性状に及ぼす影響を確認す る実験を行つた．インダクターへの電力投入は，後述す るような理由で，取鍋から注入後 $1 \mathrm{~min}$ でタンディッシ 二内に溶鋼を満たし，その時点に最大電力を投入する方 法をとつた.

タンディッシュ内溶鋼温度の測定は，サーィット製の 保護管に熱電対を挿入して連続的に行つた。

\section{$2 \cdot 1$ 加熱設備}

溝型電磁誘導炉（以後インダクターと称する）をタン ディッシュに接続した状態を模式的に Fig. 1 亿示す. インダクターは溶鋼を保持し，かつ昇温するための耐火 物から成る溝部（以後溶鋼チャンネルと称する）と, 鉄 心および誘導コイルから成る電気部分で構成される。イ ンダクターに電力を供給するための主要電気設備は，受 電船, 変圧器, サイリスタースイッチ, 力率改善コンデ ンサー, 開閉器, 水冷ヶーブル, 操作盤などから構成さ れる. 本実験では後述する理由で, 最大電力 $1070 \mathrm{~kW}$ $(50 \mathrm{~Hz})$ のインダクターを採用した。

\section{$2 \cdot 2$ 加熱原理}

インダクターは、コイル（1 次コイル相当）を貫通し た閉回路を成す鉄心と, 鉄心回路を横切る溶鋼チャンネ ル（2 次コイル相当）から構成される14) 15)。ここで 1 次コイルに電流を流すと溶鋼千ャンネル内に誘導電流が 発生する。いま, $\mathrm{N}$ ターンの1次コイルに $E_{1}[\mathrm{~V}]$ の電 圧を加兄 $I_{1}[\mathrm{~A}]$ の電流が流れたとすれば，2次コイル を形成している 1 ターンのチャンネル内溶鋼には $N I_{1}$ [A] の電流が流れる.この 2 次回路を構成する溶鋼の 抵抗を $R[\Omega]$ とすれば溶鋼には $(1)$ 式で示す熱量 [W] が発生する.

$$
W=K \cdot\left(N I_{1}\right)^{2} \cdot R=K \cdot E_{2} \cdot I_{2} \cdot \cos \varphi
$$

ここで $K$ は定数， $E_{2}, I_{2}$ はチャンネル内溶鋼にかかる
電圧，電流， $\cos \varphi$ は力率を示す。電磁誘導加熱された 溶鋼は，電磁誘導のピンチ効果 ${ }^{16}$ 亿よる溶鋼噴出，及び 相反する向きの 1 次電流と 2 次電流に起因する反発力に よつてチャンネル側から外方に押し出され，タンディッ シュ内溶鋼と激しく衝突，混合し，タンディッシュ内温 度が高められる。

\section{$2 \cdot 3$ 実験項目}

SUS-304，SUS-430 系ステンレス鋼の連続鋳造に際 して, 約 200 回の加熱実験を行つた.

鋳造条件は，電力投入に上る加熱を行ら以外はすべて 通常の鋳込条件と等しくした.タンディッシュ内の溶鋼 温度を鋳込全期間を通して一定とするために熱電対によ る連続測温值を指標にして投入電力を自動制御した.

調査は，先に示した非定常鋳込部に相当する $6 \mathrm{~m}$ 長さ の鋳片を採取し，染色探傷法により大型介在物およびピ ンホールの表面近傍 $(0 \sim 20 \mathrm{~mm})$ の分布を明らかにし た. 定常鋳込部に相当する鋳片は，スライム抽出法，X 線透過法, および酸素分析を行つて, 厚み方向集積部近 傍の介在物量を調べた。

次に製品コイルは，冷延仕上工程で表面に現れるへゲ や筋状欠陥，およびふくれ状欠陥の発生頻度を調査し た。ここで，へゲおよび筋状欠陥は，鋳片表層に存在す る大型介在物に起因し，末た，らくれ状欠陥は，鋳片内 部の介在物集積帯に存在する大型介在物に起因して発生 することをあらかじめ確認した。

\section{3. 実 験 結 果}

\section{1 溶鋼温度低下防止効果}

インダクターを使用しない通常鋳込みヒートに打い て，タンディッシュ内溶鋼温度を連続的に測定した結果 の代表例を Fig. 2 に示す.

鋳込初期の溶鋼温度は鋳込中期の平均温度に対して最 大 $10 \sim 20^{\circ} \mathrm{C}$ 低下し，末期は 5 10 ${ }^{\circ} \mathrm{C}$ 低下，取鍋交換 時には, 次ヒートの溶鋼温度により程度が異なるが, $5 \sim 8^{\circ} \mathrm{C}$ の低下が認められる。 また，取鍋からタンディ ッシュへの給湯開始 $1 \mathrm{~min}$ 後の測温值は, 鋳込中期の平 均温度と良く一致することから, 温度降下量の表示に際 しては, 以後給湯 $1 \mathrm{~min}$ 後の測温値を基準にして示す.

\section{$3 \cdot 1 \cdot 1$ 鋳込初期の溶鋼加熱効果}

鋳込初期にタンディッシュ内の溶鋼を効率よく加熱し て温度降下を防止するには，取鍋からタンディッシュへ の給湯後できるだけ早く大きな電力を投入する必要があ る. しかし鋳込みのごく早い時期，すなわちタンディッ シュ内溶鋼の湯面高さがまだ低い時期に大きい電力を投 入すると以下に述べるような電気的不安定現象を生じ 


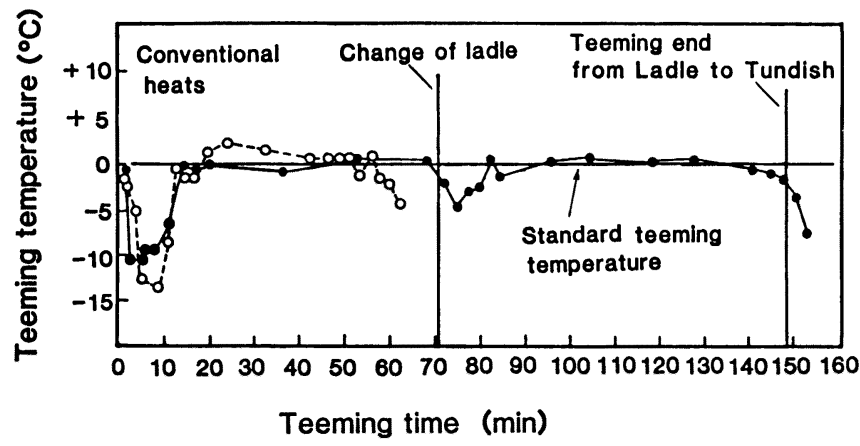

Fig. 2. Temperature change of molten steel of conventional heats in tundish.

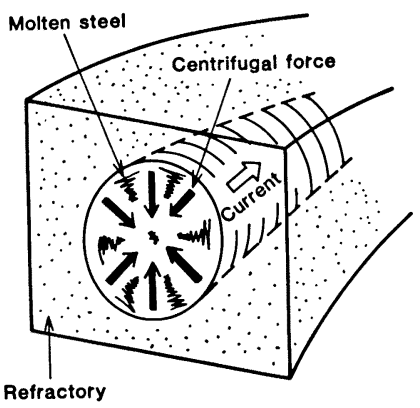

Fig. 3. Centrifugal force in the channel of tundish-heater.

て，安定した溶鋼加熱が阻害されることがある.

すなわち，チャンネル内溶鋼には通電に伴ら電磁力の 作用によつて，Fig. 3 に示すように向心方向への締め 付け力が働く (ピンチ効果). 締め付け力は投入する電 力が大きくなるに従つて大きくなり，ある限界を越える と溶鋼断面積の縮小, ひいては, 溶鋼の断路状態を引き 起こす，一方，溶鋼静圧は，断路に伴つて生じる負圧部 への溶鋼供給を行い, 溶鋼の断路状態を改善する.

鋳込初期の鋼浴レベルが小さい時期には溶鋼静圧が小 さいために締め付け力に対する抑制力が小さく，電気的 不安定の原因となる.

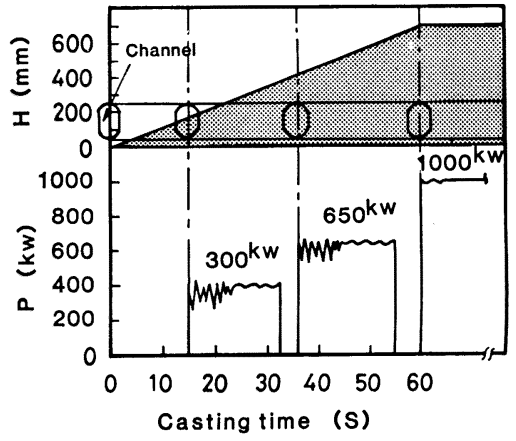

Fig. 4. Good example of put in power at the start of casting with regarding the pinch effect.

そこで，鋳込初期の種々の鋼浴深さに対する投入電力 の電気的安定度をロードバランサーにかかる電流值の変 化を実測することによつて求めた. 電気的安定性は鋼浴 深さと直線的な関係があり, 深さが増す汪ど大きい電力 が安定して供給でき， $600 \mathrm{~mm}$ 以上では本設備最大の $1000 \mathrm{~kW}$ が安定して投入できる.

以上の結果から，鋳込初期の最適電力投入パターンの 一例として Fig. 4 が得られる. 鋼浴深さに応じて投入 電力を大きくし, かつ, 最大電力投入時期を早くするこ とが効率的な加熱を行ら条件である.

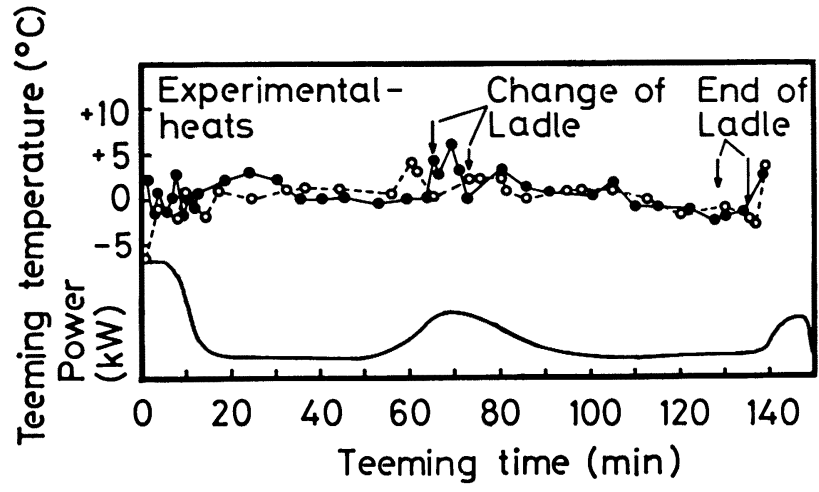

Fig. 5. Temperature change of molten steel in tundish during whole cast. 


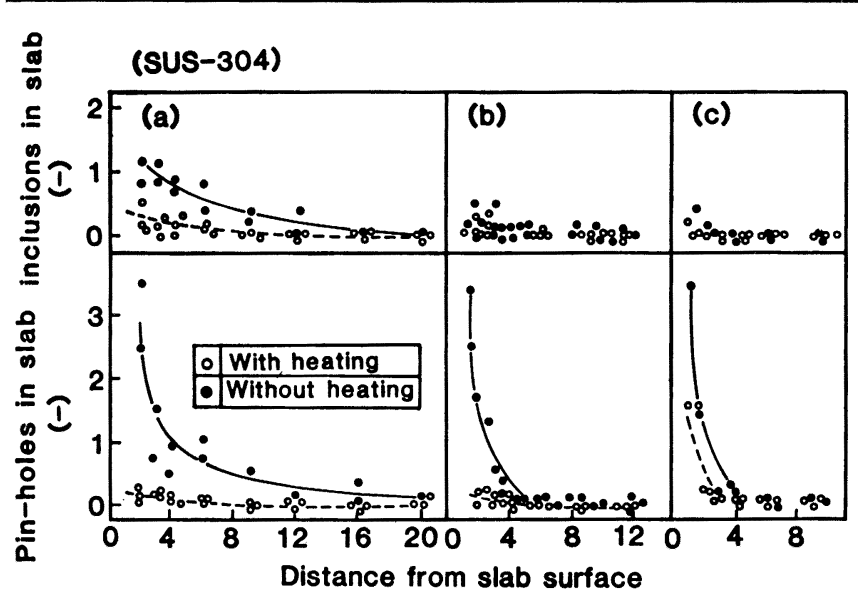

(a) First slab (b) Ladle change slab (c) End slab

Fig. 6. Distribution of inclusions and pin-holes in slab.
鋳込初期のタンディッシュ内溶鋼の温度降下量の最大

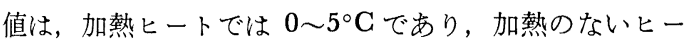
トの $10 \sim 20^{\circ} \mathrm{C}$ に比較して著しく改善できた. 同時に温 度降下の回復も早く, 加熱のないヒートの約 $13 \mathrm{~min} に$ 対して, 約 $6 \mathrm{~min} に$ 短縮できた.

$3 \cdot 1 \cdot 2$ 鋳込末期および取鍋交換時の溶鋼加熱効果 鋳込末期と取鍋交換部を含む, 鋳込全期間の溶鋼温度 制御例を Fig. 5 に示す. 鋳込初期と比較して温度降下 量が少ないこれらの時期においては, 最大電力の約 $1 / 2$ 負荷により温度降下をほぼ完全に防止できる。

\section{2 鋳片品質改善効果}

\section{$3 \cdot 2 \cdot 1$ 非定常部鋳片の表皮下介在物の低減}

SUS-304 の非定常部鋳片について表皮下の大型介在 物およびピンホールの測定結果を Fig. 6 に示す. これ らの欠陥の個数は, 加熱の実施により著しく減少し, 加 熱を行わないヒートからの鋳片と比較して 1/4〜1/12 に なり, 定常部鋳片の表面品質とほぼ同程度にまで改善で きた。

これらの結果をもとにして, 非定常部相当鋳片の表面 手入れ量は, 定常部鋳片と同程度にまで軽減することが できた.このような鋳片表層部の大型介在物，およびピ

Table 1. Typical composition of large inclusions in slab subsurface. (wt $\%)$

\begin{tabular}{c|c|c|c|c|c|c|c|c}
\hline $\mathrm{n}$ & $\mathrm{CaO}$ & $\mathrm{SiO}_{2}$ & $\mathrm{Al}_{2} \mathrm{O}_{3}$ & $\mathrm{MnO}$ & $\mathrm{FeO}$ & $\mathrm{Cr}_{2} \mathrm{O}_{3}$ & $\mathrm{Na}_{2} \mathrm{O}$ & $\begin{array}{l}\text { Composi- } \\
\text { tion }\end{array}$ \\
\hline 1 & 38.3 & 38.2 & 8.6 & 0.95 & 0.63 & 0.84 & 12.2 & $\mathrm{M}$ \\
\hline 2 & 40.2 & 39.0 & 8.2 & 1.26 & 1.26 & 0.73 & 9.2 & $\mathrm{M}$ \\
\hline 3 & 16.6 & 23.1 & 5.8 & 1.14 & 40.0 & 11.2 & 1.9 & $\mathrm{M}+\mathrm{R}$ \\
\hline 4 & 8.3 & 29.3 & 2.3 & 13.3 & 32.7 & 10.6 & 3.3 & $\mathrm{M}+\mathrm{R}$ \\
\hline \multicolumn{6}{c}{$\mathrm{M}:$ Mold flux } \\
\hline \multicolumn{6}{c}{$\mathrm{C}$. Reoxidation Products by Air }
\end{tabular}

ンホールの低減効果は, Table 1 に示す通常工程ヒート における非定常部鋳片表層の大型介在物組成から考え て，モールドパウダーの溶融状態が改善されたこと，お よび溶鋼の再酸化物や脱酸生成物がタンディッシュ内お よびモールド内で浮上分離しやすくなつた結果と推定で きる。

\section{$3 \cdot 2 \cdot 2$ 製品コイルの表面品質改善}

製品コイル表面に見られる欠陥のタイプは, 原因とな る介在物の鋳片内厚み方向に和ける存在位置によつて二 つに分類できる. 表層近傍に存在する場合は, 筋状また

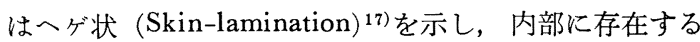
場合は，ふくれ状 (Seam defect) ${ }^{17)}$ となる.

製品コイルの表面欠陷発生状況を Fig. 7 に示す. 加 熱を行つたヒートのコイルでは, 上記いずれの欠陷も減 少することが明らかになつたが, 大型介在物以外の要 因，例光ば，加熱，圧延条件の微妙な変化により発生す る微小割れ，などが原因と考えられる筋状欠陥に対する よりも大型介在物のみに起因するふくれ状欠陥の方が,
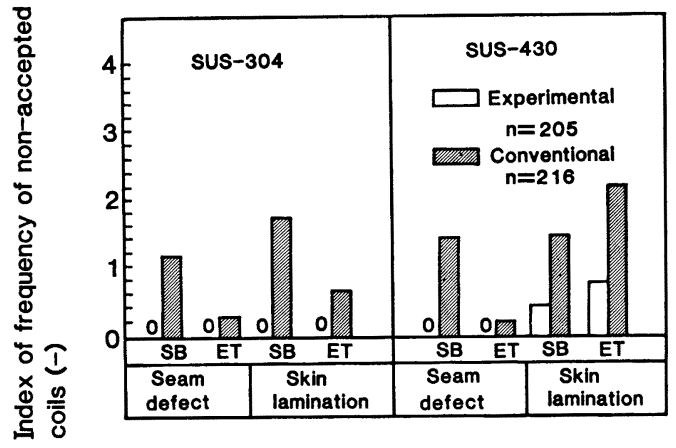

SB : First slab, ET : End slab

Fig. 7. Surface defects on the stainless steel cold rolled coils. 


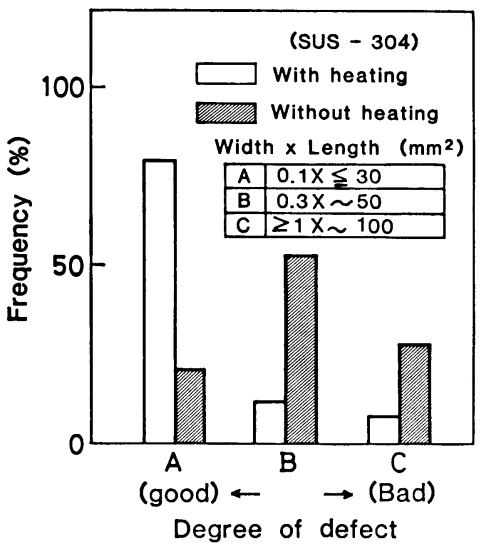

Fig. 8. Surface defect of cold sheet.

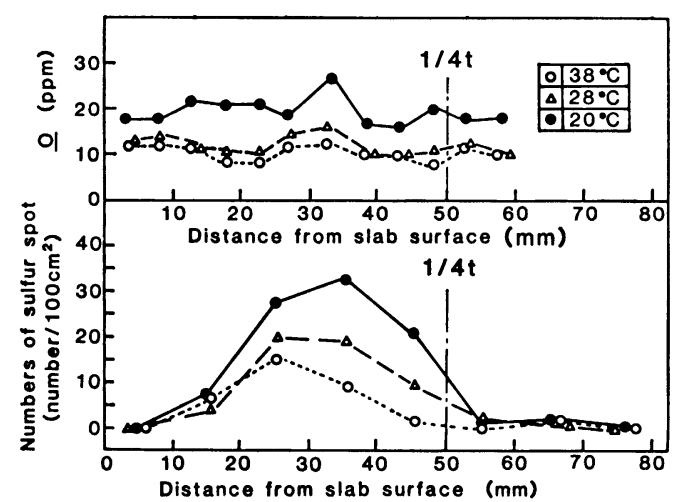

Fig. 9. Relation between the quality of slabs of $0.15 \% \mathrm{C}$ steel and casting temperature.

より低減効果が大きい。しかし筋状欠陷も詳細に観察す ると Fig. 8 に示すよらに, 欠陥部の長さと幅から決ま る欠陥の大きさの程度は溶鋼加熱を行らことによつて軽 微になる.これらの軽微な欠陷からは非金属介在物が検 出されないことが多く，製鋼要因以外の原因によつて生. じる種類のものである.

\section{$3 \cdot 2 \cdot 3$ 定常部鋳片の内部介在物低減}

鋳造時に同一ヒート内で投入電力を変化させて溶鋼過 熱度 $(\Delta T)$ を, 加熱しない状態の $20^{\circ} \mathrm{C}$ から $28^{\circ} \mathrm{C}$ さ らに $38^{\circ} \mathrm{C}$ まで変化させた．各温度における鋳片内部介 在物量を Fig. 9 に示す. 大型介在物，拉よび非金属介 在物総量に対応するO分析値のいずれも，過熱度が大き くなるに従つて減少し， $\Delta T$ が $20^{\circ} \mathrm{C}$ から $38^{\circ} \mathrm{C}$ に大き くなると大型介在物は $36 \%$ に減少しO值も $60 \%$ に低 減した.

鋳込中期において，しかも，ほぼ等しい介在物量を有 する同一ヒートの母溶鋼によつて温度条件のみを変化さ
せることが可能となつたが，このような確性試験によつ て，各鋼種に応じた最適の鋳造温度が選択できるよらに なり連鋳操業の安定化が期待される.

\section{4. 考察}

\section{$4 \cdot 1$ タンティッシュ内溶銅の熱収支}

加熱設備を小規模にし，かつ操業を簡単にするために 加熱を行わない通常工程ヒートにおけるタンディッシュ 内溶鋼温度の推移から，タンディッシュ内溶鋼の熱収支 を検討し，温度低下が鋳込中最大となる鋳込初期の温度 低下を防止するに必要な最適電力を見積もつた。

いま，タンディッシュ内溶鋼温度が均一であり，取鍋 からタンディッシュへの給湯速度とタンディッシュから モールドへの注入速度が等しいと仮定すると, タンディ ッシュ内溶鋼の熱収支は (2) 式18)で与えられる.

$$
C_{p} \cdot W \frac{d T}{d t}=C_{p} \cdot Q\left(T_{L}-T\right)-H_{L}
$$

ここで, $C_{p}:$ 溶鋼比熱 $\left[\mathrm{kcal} / \mathrm{kg} \cdot{ }^{\circ} \mathrm{C}\right]$

$W:$ タンディッシュ内溶鋼重量 $[\mathrm{kg}]$

$Q:$ 溶鋼の流入および流出速度 $[\mathrm{kg} / \mathrm{s}]$

$T:$ タンディッシュ内溶鋼温度 $\left[{ }^{\circ} \mathrm{C}\right]$

$T_{L}:$ 取鍋内溶鋼温度 $\left[{ }^{\circ} \mathrm{C}\right]$

$t:$ 時間 [s]

$H_{L}$ : タンディッシュからの全放熱量 [ $[\mathrm{kcal} /$ s ]

いま，鋳込初期の実測温度推移をパターン化して示す と Fig. $10 \mathrm{a}$ のよらになる. 温度低下はAが最大，Cは 最少，囚は中間である．実際にはBの出現頻度が最も高 い.

溶鋼温度の基準点を取鍋注入開始 $1 \mathrm{~min}$ 後（タンディ

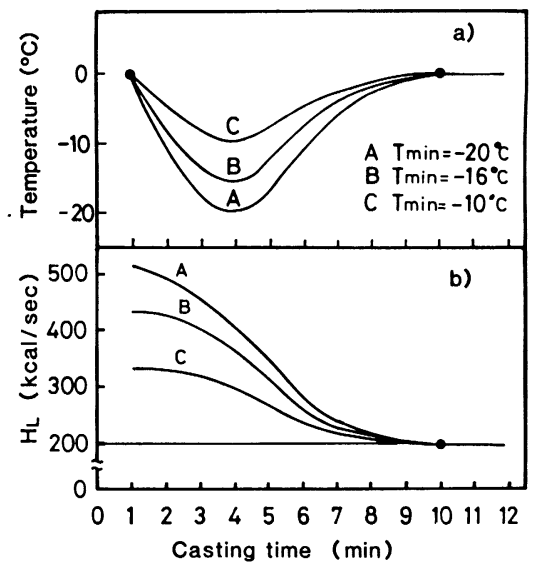

Fig. 10. Temperature change of molten steel in tundish and heat transfer rate by modeling. 


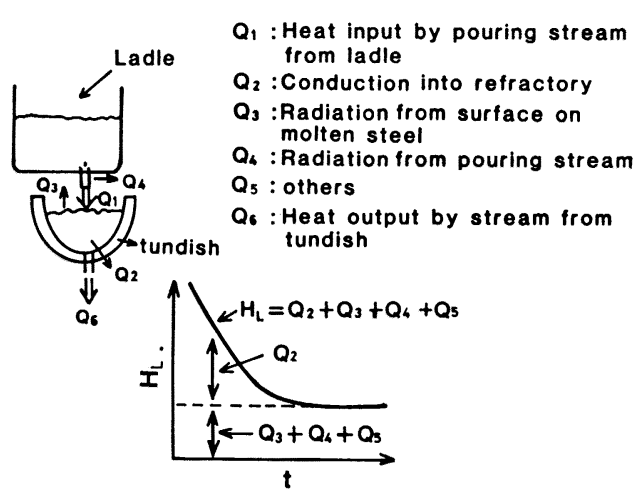

Fig. 11. Schematic diagram of heat balance from molten steel in tundish.

ッシュ満杯時に相当) とし，この $t=0$ において $T=0$, とすると (2) 式からタンディッシュ内溶鋼温度は $(3)$ 式 のように求まる.

$$
T=\left(\Delta T_{L}-\frac{H_{L}}{C_{p} \cdot Q}\right)\left[1-\exp \left(-\frac{Q}{W} t\right)\right] \ldots
$$

ここで $\Delta T_{L}=T_{L}-T_{0}\left(T_{0}\right.$ は目標温度) である.今， $\Delta T_{L}=40^{\circ} \mathrm{C}$ とし, 時間 $(t)$ と温度 $(T)$ を代入する と各パターンにおける放熱速度 $\left(H_{L}\right)$ が Fig. $10 \mathrm{~b}$ の よらに求められる.

タンディッシュ内溶鋼の放熱経路はFig. 11 に模式図 で示すように耐火物への吸熱 $\left(Q_{2}\right)$, 鋼浴表面からの放 熱 $\left(Q_{3}\right)$, 取鍋とタンディッシュ間の注入流からの放熱 $\left(Q_{4}\right)$ ，その他 $\left(Q_{5}\right)$ と考光られる. $Q_{2}$ は鋳込初期で

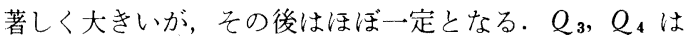
鋳込中一定と考えられるので時間に依存しない項であ る. 鋳込初期の数分間の大きな放熱は時間依存項であ り，耐火物への吸熱 $Q_{2}$ が大きく影響し，その後は $200 \mathrm{kcal} / \mathrm{s}$ 一定の放熱速度を示す.

鋳込初期の温度降下を防止するためには, タンディッ シュからの放熱速度 $\left(H_{L}\right)$ を上回る加熱エネルギーを 与える必要がある. 加熱を行う場合は, (2)式の右辺に 加熱エネルギー $\left(H_{h}\right)$ が入熱項として加わり (4) 式で 示される.

$$
C_{p} \cdot W \frac{d T_{h}}{d t}=C_{p} \cdot Q\left(T_{L}-T_{h}\right)-H_{L}+H_{h}
$$

加熱時の熱収支と, 無加熱時の熱収支との差から, 加熱 効果は (5)式のように求まる.

$$
\begin{gathered}
C_{p} \cdot W^{\frac{d \Delta T^{\prime}}{d t}}=-C_{p} \cdot Q \cdot \Delta T+H_{h} \cdots \cdots . \\
\text { ただし, } \Delta T^{\prime}=T_{h}-T, \text { ここで, }(5) \text { 式 } \\
\Delta T^{\prime}=0 \text { として解くと(6) 式が得られる. } \\
\Delta T^{\prime}=\frac{H_{h}}{C_{p} \cdot Q}\left[1-1.239 \exp \left(-\frac{Q}{W} t\right)\right] \cdots
\end{gathered}
$$$$
\text { ただし， } \Delta T^{\prime}=T_{h}-T \text { こここで, (5)式を, } t=60 \mathrm{~s} \text { で }
$$

(6) 式に今回の実験条件, $C_{p}\left(0.2 \mathrm{kcal} / \mathrm{kg} \cdot{ }^{\circ} \mathrm{C}\right), W$ $(7000 \mathrm{~kg}), \quad Q(25 \mathrm{~kg} / \mathrm{s}), \quad H_{h}$ として電力 $P\left(H_{h}=\right.$ $0.239 \mathrm{PkW})$ を入れると( 7 ) 式が得られる.

$$
\Delta T^{\prime}=0.048 P[1-1.239 \exp (-0.00357 t)]
$$

(7) 式による計算結果をFig. 12 に示す. 鋳込初期の 温度低下の防止に必要な電力は $1000 \mathrm{~kW}$ 以上であり, これが本実験において $1000 \mathrm{~kW}$ のインダクターを選定 した理由である.

ここで，投入電力の熱効率を次項に示すように $85 \%$ とし，鋳込初期の温度降下に及ぼす最大電力投入時期の 影響を計算してFig. 13 に示す. 投入時期は早い方が良 く, 取鍋からタンディッシュに給湯後早期に $1000 \mathrm{~kW}$ を投入することによつて温度降下をほぼ 0 にでさる。

\section{$\mathbf{4} \cdot 2$ 加熱効率の見積もり}

溝型インダクターの加熱効率は一般的に大きいと言われ ている(19) 20). 本実験のインダクタ一の熱効率を, (6) 式により求めた $\Delta T^{\prime}$ と実測値から求めて Fig. 14 に示 す. 加熱効率は 70〜 $100 \%$ の範囲にあり，平均 $85 \%$ と 高い值を示している.

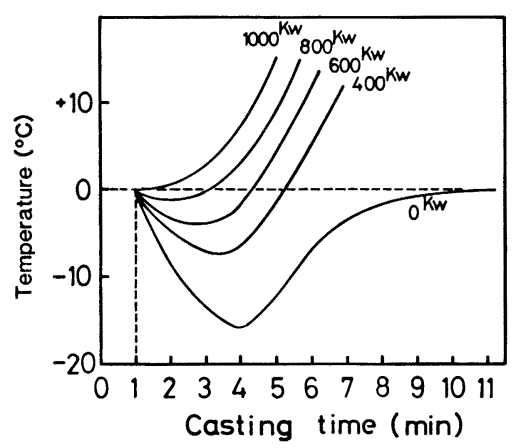

Fig. 12. Temperature change of molten steel in tundish by heating at the casting start.

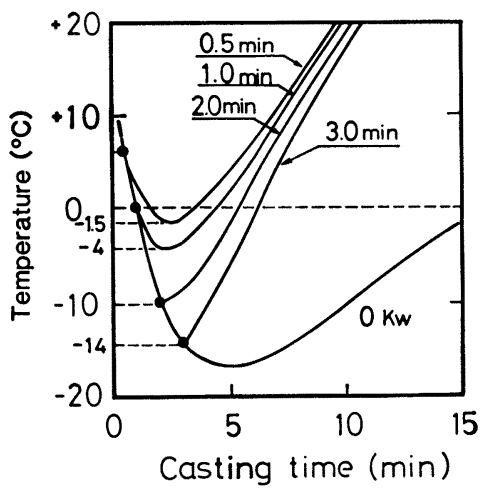

Fig. 13. Relation between time required to put in full power and temperature. 


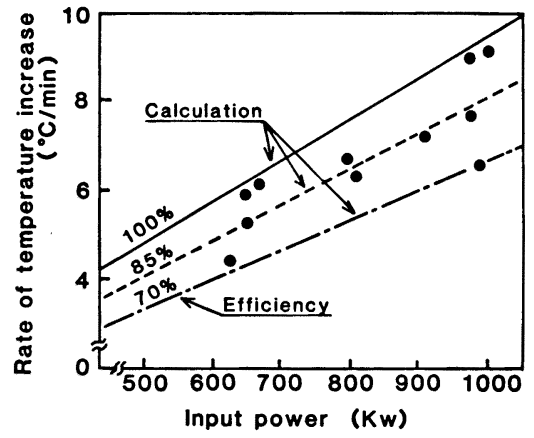

Fig. 14. Relationship between rate of temperature increase and input power.

一方，水冷ジャケットやインダクター外壁および誘導 コイルの冷却水への放熱量は電力換算で 10 15\% に相 当することから，上記の $85 \%$ は妥当な值であると考え る.

\section{$4 \cdot 3$ ピンチカ制御法の検討}

インダクターチャンネル内で加熱された溶鋼は, ピン

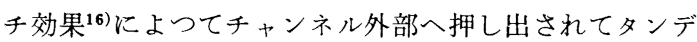
ィッシュ内溶鋼と混合して均一温度となる. しかし，ピ ンチ現象が大きくなり, 溶鋼断面積に変化が生じると安 定した加熱ができなくなる，さらに大きなピンチ現象が 生ずると耐火物に損傷21) 22) を与えることもある，そこ でこのような電気的不安定を防止する方法を検討する.

電磁力により生じる溶鋼の締め付け力 $\left\langle P_{d}\right\rangle\{\mathrm{Pa}(\mathrm{N} /$ $\left.\left.\mathrm{m}^{2}\right)\right\}$ は (8)式で与えられる

$$
\left\langle P_{d}\right\rangle=\frac{\mu_{r} \cdot \mu_{0} \cdot I_{2}^{2}}{8 \pi A}
$$

ここで, $\mu_{r}:$ 溶鋼の比透磁率 $(\cong 1)$

$\mu_{0}:$ 真空の透磁率 $\left(4 \pi \times 10^{-7}\right)$

$I_{2}:$ チャンネル内溶鋼を流れる電流 $(\mathrm{A})$

$A:$ チャンネル断面積 $\left(\mathrm{m}^{2}\right)$

一方，締め付け力による溶鋼断面積の変化に対して は，それを抑制し，断面積を一定に保持しようとする力 $\left(P_{s t}\right)(\mathrm{Pa})$ は $(9)$ 式で与えられるように溶鋼静圧であ る.

$$
\left(P_{s t}\right)=P_{0}+\rho g h
$$

ここで, $P_{0}$ は大気圧 $\left(\mathrm{N} / \mathrm{m}^{2}\right), \rho$ は溶鋼の密度 $(\mathrm{kg} /$ $\left.\mathrm{m}^{3}\right), g$ は重力の加速度 $\left(\mathrm{m} / \mathrm{s}^{2}\right), h$ はメニスカスまでの 溶鋼深さ $(\mathrm{m})$ である. したがつて, 電気的不安定を生 じさせないためには， $\left.\left(P_{s t}\right)\right\rangle\left\langle P_{d}\right\rangle$ が成立せねばならな い.

いま， $1000 \mathrm{~kW}$ の電力を投入した場合の $\left(P_{s t}\right)$ およ び $\left\langle P_{d}\right\rangle$ を求めると, $\left\langle P_{d}\right\rangle$ は $1.5 \times 10^{4} \mathrm{~Pa}\left(\mathrm{~N} / \mathrm{m}^{2}\right)$ であり, $\left(P_{s t}\right)$ は $1.1 \times 10^{5} \mathrm{~Pa}(h=10 \mathrm{~cm}) \sim 1.5 \times 10^{5} \mathrm{~Pa}$ $(h=70 \mathrm{~cm})\left(\mathrm{N} / \mathrm{m}^{2}\right)$ となり, チャンネル内が溶鋼で 満 たされているかぎり $\left.\left(P_{s t}\right)\right\rangle\left\langle P_{d}\right\rangle$ が成立する.

しかし，実操業で鋳込初期に安定して $1000 \mathrm{~kW}$ が投 入できるのは鋼浴深さが $600 \mathrm{~mm}$ 以上においてであり上 と矛盾する. 鋳込初期においては, チャンネル内にはタ ソディッシュ内の雾囲気ガスや耐火物からのガスや水蒸 気などの気泡が残留していると考えられるが，このよう なガス気泡の存在は溶鋼断面積を小さくすることになり (8) 式の〈P $\left.P_{d}\right\rangle$ を大きくすることになるので, これが鋳 込初期に実操業と計算值の違いになつている原因と考え られる.

そこで，チャンネル内にガス気泡を残留させない対策 が必要となるが，それにはチャンネル内の気泡が浮上し やすいように傾斜を設けることやチャンネル内溶鋼流速 を大きくする23) 24)ことが有効であると考える.

\section{4 溶鋼清浄化のメカニズム}

タンディッシュ内溶鋼加熱による溶鋼清浄化のメカ二 ズムは，1）タンディッシュ内およびモールド内におけ る介在物の浮上促進, 2) モールドパウダーの溶融性の 改善などが考えられる，上記 1$)$ のタンディッシュ内で の浮上に関しては，1）攪挥力の増大により介在物が凝 集肥大化しやすくなること.2) フローパターンの改善 により介在物が浮上促進しやすくなることの二つが考え られる．そこで前記 1) のメカニズムに着眼し, 溶鋼攪 找力の大きさを $\mathrm{Cu}$ 添加法により検討した.

タンディッシュの取鍋溶鋼落下点に $\mathrm{Cu}$ を投入する と, タンディッシュ出口における $\mathrm{Cu}$ 濃度, $C_{\text {out }}$ は (10)式25)で示される.

$$
C_{\text {out }}=C_{0} \cdot E(\theta)
$$

ここで, $C_{0}$ は初濃度, $E$ は滞留時間分布関数, $\theta$ は 無次元時間である. 分散の定義 ${ }^{25)} に よ り ~ \sigma^{2}$ は(11)式の ように求まる.

$$
\begin{aligned}
\sigma^{2} & =\frac{\int_{0}^{\infty}(\theta-1)^{2} E(\theta) d \theta}{\int_{0}^{\infty} E(\theta) d \theta}=\frac{\sum(\theta-1)^{2} E(\theta) \Delta \theta}{\Sigma E(\theta) \Delta \theta} \\
& =\frac{\sum \theta^{2} E(\theta)}{\sum E(\theta)}-1 \ldots \ldots \ldots \ldots \ldots \ldots \ldots \ldots \ldots \ldots \ldots \ldots \ldots \ldots \ldots \ldots \ldots \ldots \ldots
\end{aligned}
$$

一方，拡散モデルによる $\sigma^{2}$ は(12)式 ${ }^{26)}$ でちられ る.

$$
\sigma^{2}=\frac{2}{P e^{2}}\{P e-1+\exp (-P e)\}
$$

ここで $P e$ はペクレ数を示す. 実験により $(11)$ 式で計 算した $\sigma^{2}$ が(12)式の $\sigma^{2}$ と等しいとして解くと $P e$ 数 が求まる. 得られた結果をFig. 15 に示す. 


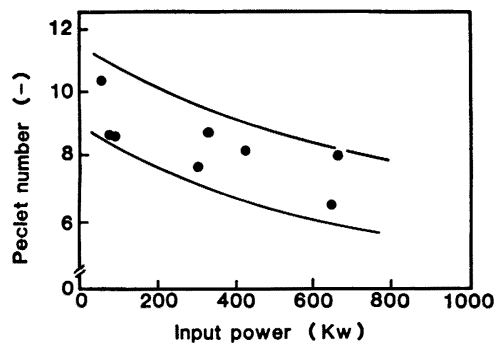

Fig. 15. Effect of input power on peclet number.

$P e$ 数は投入電力が大きくなるに従つて小さくなる. すなわち，インダクターへの投入電力が大きくなるほど 溶鋼の靦找力が大きくなることを示しており，前記の1) のメカニズムである介在物凝集肥大化によつて溶鋼の清 浄化が計られる可能性が大きいことが明らかになつた.

しかし，前記の他の要因の寄与も十分に考えられ，こ の点の定量的解明が今後の課題である.

なお，本実験のインダクターを用いることによりタン ディッシュ内溶鋼の温度制御が可能となるので，各鋼種 に応じて最適温度の設定が可能となり，また，中心偏析 防止を目的とした低温鋳造など，連続鋳造の安定化に広 く適用できる利点がある。

\section{5. 結 \\ 言}

連続鋳造時の鋳込初期や末期，および取鍋交換時など の非定常部スラブの品質を改善するための新しい試みと して，溝型電磁誘導方式のヒーターを開発して，ステン レス鋼鋳造時のタンディッシュ内溶鋼を加熱する実験を 行い, 以下の結論が得られた.

1) 鋳込初期のタンディッシュ内溶鋼温度低下は 0〜 $5^{\circ} \mathrm{C}$ であり，加熱を行わないヒートの $10 \sim 20^{\circ} \mathrm{C}$ に比べ て著しく改善できた。熱効率は 70〜100\%，平均 85\% であつた。

2) 鋳片表皮下の大型介在物量は，加熱を行わないヒ 一トの場合に比較して 1/4 1/12 に減少することがで きた。

3 ) 製品コイル表面の筋状およびふくれ状欠陥は大幅 に低減できた.このよらな溶鋼清浄化のメカニズムの一 つとして，タンディッシュ内溶鋼の強靦拌が有効である ことを示した.

\section{交献}

1）川上公成：鉄と鋼，67 (1981)，p. 1080
2 ) 友野宏, 尾崎孝三郎，浦知，岩田勝吉，鈴 木俊明：鉄と鋼， 69 (1983)，S 914

3 ) 森 隆資：鉄と鋼，67 (1981)，p. 1101

4 ) 吉井裕, 垣生泰弘, 江見俊彦, 森脇三郎, 越川 隆雄, 今井卓雄：鉄と鋼, 64 (1978), S 626

5 ) 吉田基樹, 石飛精助, 脇田淳一，溝口庄三：鉄と 鋼, 66 (1980), S 863

6 ）小舞忠信, 宮村 紘, 大崎真弘, 草野昭彦, 山田 哲，島津 勲，佐藤憲夫，山本和文：鉄と鋼，67 (1981), p. 1152

7 ) 塗 嘉夫, 梅沢一誠, 大橋徹郎, 伊藤 良, 溝口 良平，横井真一：鉄と鋼，69 (1983)，S 989

8 ) 駒村宏一, 久口湊英雄, 小嶋英明, 越川隆雄, 上 杉浩之，児玉正範，吉井 裕，垣生泰弘，江見俊 彦: 鉄と鋼, 67 (1981), A 133

9 ) 小原昭彦, 桜井美弦, 德繁次郎, 越川隆雄, 針田 涁，垣生泰弘，吉井 裕：鉄と鋼，69（1983), S 208

10) 吉井 裕, 垣生泰弘, 内村良治, 木下勝雄, 山中 啓充，上田典弘，針田 涁：鉄と鋼，69 (1983)， S 209

11) 吉井 裕, 野崎 努, 垣生泰弘, 上田典弘, 垣内 博之，内藤雅夫：鉄之鋼，69(1983)，S 931

12) 佐藤哲雄, 上田典弘, 桜井美弦, 木下勝雄：鉄之 鋼, 70 (1984), S 265

13) 馬淵昌樹, 吉井裕, 野崎 努, 垣生泰弘, 柿原 節雄，上田典弘：鉄と鋼，70(1984)，S 840

14) 電気工学ハンドブック（電気学会編） (1978), p. 1586

15) D. P. Kanicki: Modern Casting (1981) A pril, p. 52 [American Foundrymen's Society]

16）日本電気炉工業会誘導炬部会標準化専門委員会 編：工業加熱，2(1965) 4, p. 159

17) $A . R$. Obman, $W . T$. Germanoski and $R$. $C$. Sussman: Steelmaking Proceeding, 64 (1981), p. 254

18）藤井徹也，垣生泰弘，大井 浩：鉄と鋼，57 (1971)，p. 1648

19）鉄鋼便覧（II）（日本鉄鋼協会編）(1979)，p. 567 [丸善]

20）畠山忠之：電気加熱技術情報, (1981) No. 5, p. 18

21）工業炉ハンドブック（日本工業炉協会編）(1978), p. 171

22) $R$. E. Hammarlund: Foundry trade journal, January 13 (1966), p. 21

23) $R$. D. Langman: Br Foundryman, 74 (1981) 9, p. 178

24) D. Schluckebier: 私信

25) M. A. Shah and D. Roberts: Chemical Reaction Engineering Second Edition (1972), p. 263

26) 鞭嗾, 森山 昭: 治金反応工学 (1972), p. 113 [養賢堂] 